\title{
AGRICULTURAL SOURCES OF INFORMATION FOR WORKERS OF SHABWA AND HADRAMOUT IN THE REPUBLIC OF YEMEN
}

(Received: 3. 4. 2013)

\author{
By \\ A. A. Alzaidi, E. A . El-Hag and Z. A. Hashal \\ Department of Agricultural Extension and Rural Society, Faculty of Food and Agricultural Sciences, \\ King Saud University, Saudi Arabia
}

\begin{abstract}
The main objective of this research was to identify the sources of agricultural information to the extension workers in the Governorates of Shabwah and Hadhramout, and explore the extension workers' socioeconomic characteristics and its relationship with the agricultural information sources they used.

Data were collected through mail questionnaire which was sent to all of the 158 extension workers in the research area, 149 questionnaires $(94,3 \%)$ were completed and returned. Percentages, mean, standard deviation, correlation coefficient (Spearman correlation coefficient), were used to analyze the data, using SPSS17.

The results are summarized as follows:

- About $50.3 \%$ of the extension workers aged under 41 years with 42 years average, and $53.7 \%$ attained a graduate or postgraduate level of education. On the other hand, only $8 \%$ of the extension workers are specialized in the field of agricultural extension, and more than $67 \%$ have grown up in villages and have long years of experience in agriculture and agricultural extension work as well.

- The most important sources of information for the extension workers were the extension bulletins, co-workers, research centers, books and scientific references.

- Significant relationships were observed between some of the extension workers' characteristics and their level of use of some sources of agricultural information.

- More emphasis should be given to training programmes for extension workers as well as the official sources of information.

Key words: agricultural sources of information, extension workers, Republic of Yemen, socioeconomic characteristics.

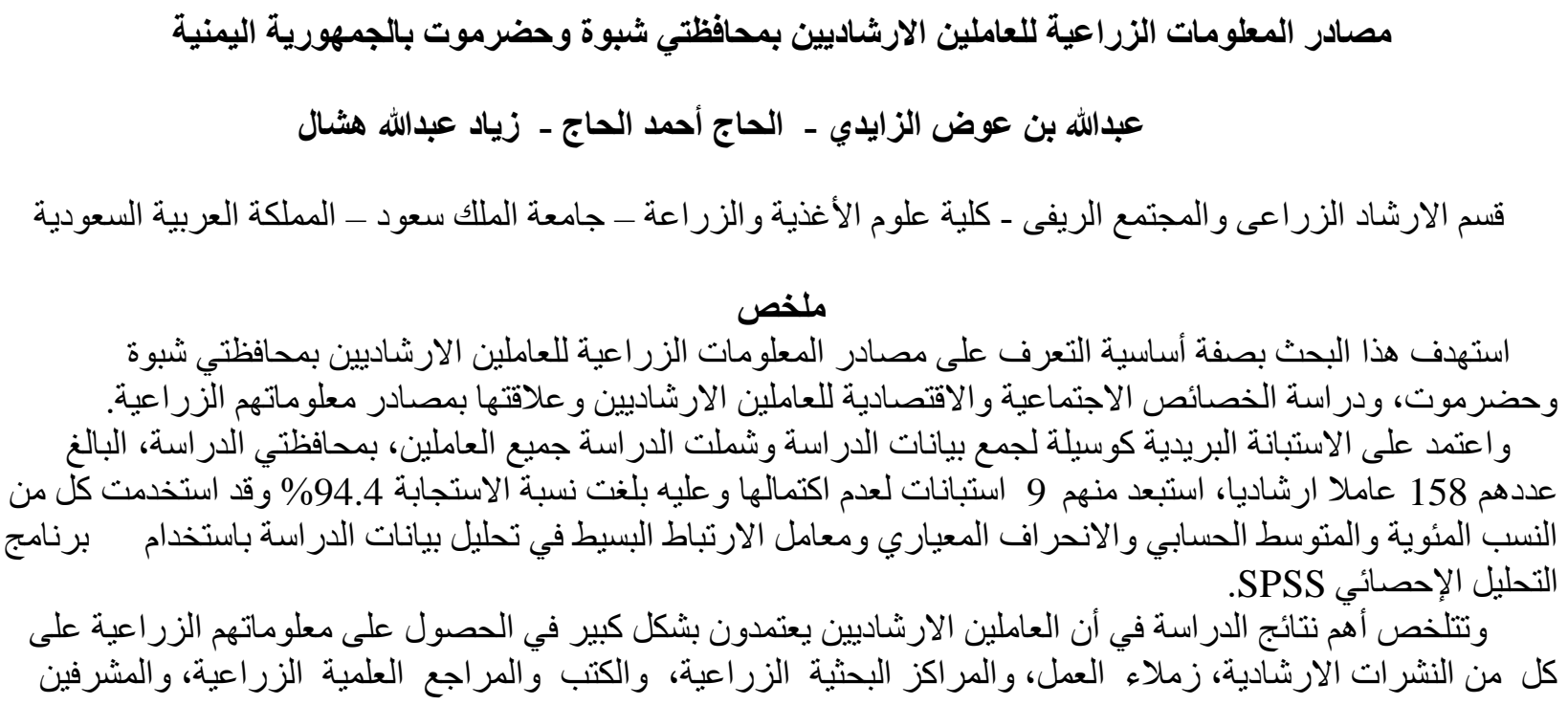




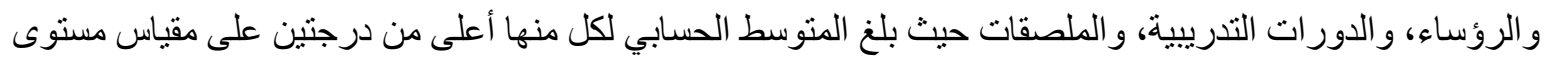

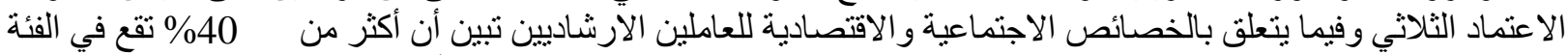

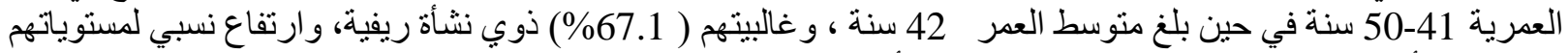

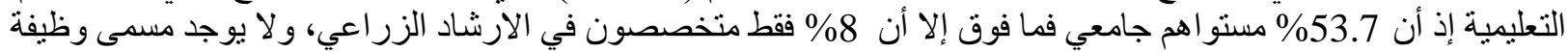

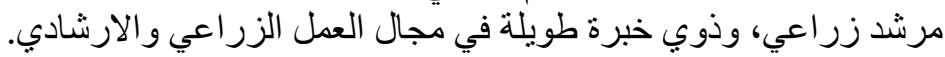

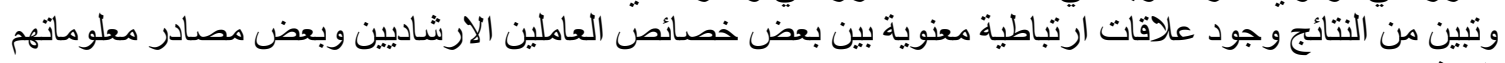
الزراعية.

أعمال الإرشاد الزراعي يعتمد على أداء العاملين

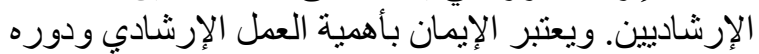

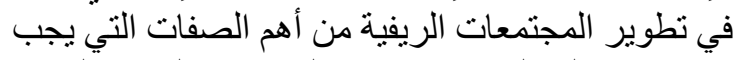

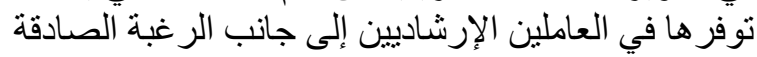

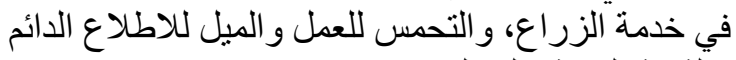

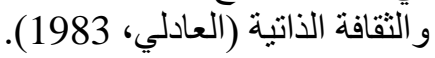

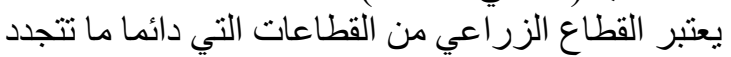

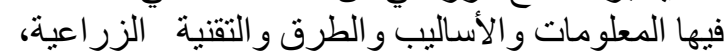

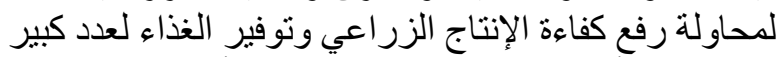

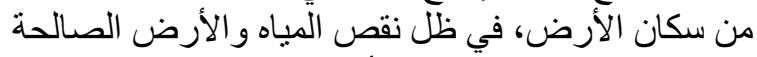

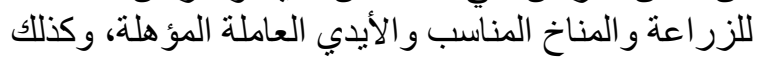

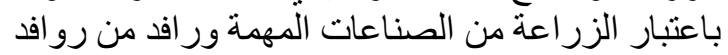

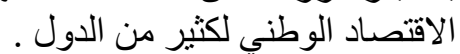

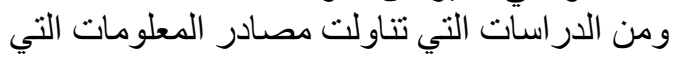

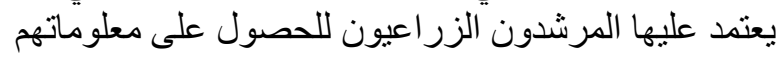

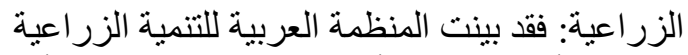

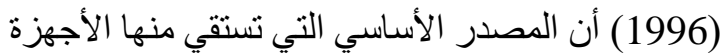

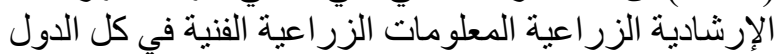

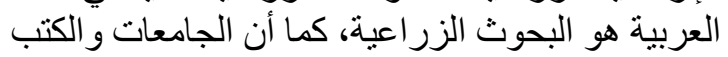

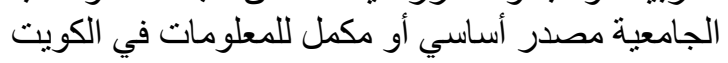

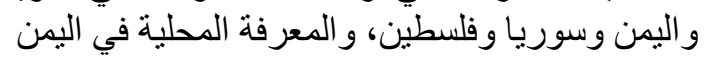

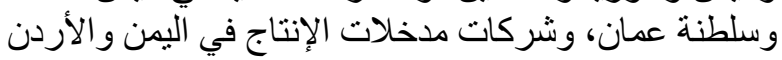

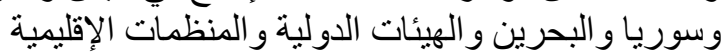

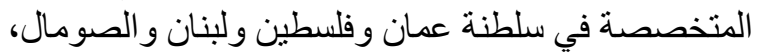
و الاستشاريون و الاختصاصيون مصدر للمعلون ولينان وات في

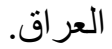

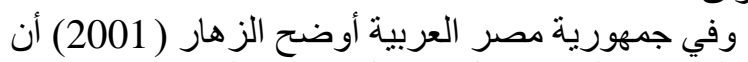
أهم المصادر التي يحصل منها المرشدون الزئ الزر اعيون

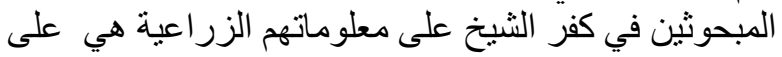

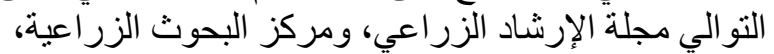

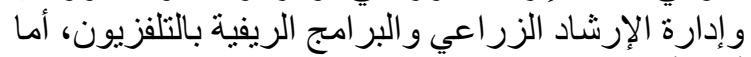

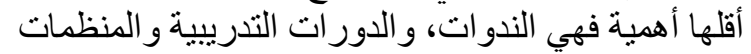
الرسمية بالقرية، وكليات الزرات الزاعة.

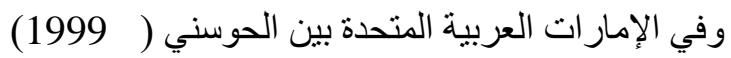

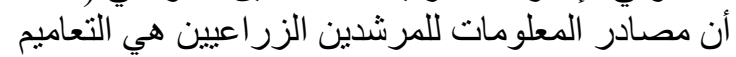

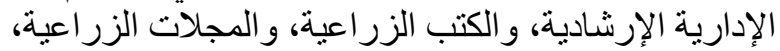

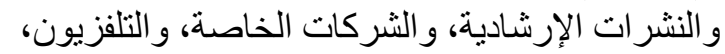

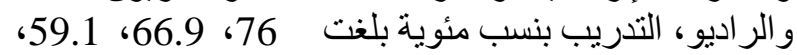

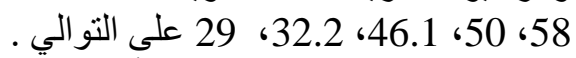

وفي المملكة العربية السعودية أوضح الفهيقي (1996)

\section{- 1 - المقدمة}

يعد القطاع الزر اعي من أهم القطاعات الإنتاجية

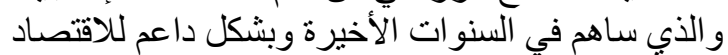

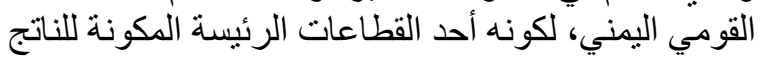

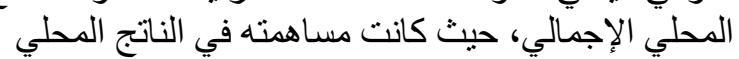
الإجمالي ما بين 10-15\%، بالإضافة إلى كونه القطاع الإن

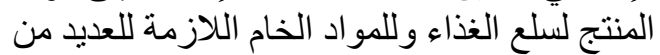

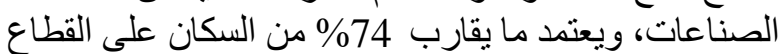

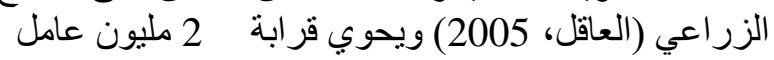
يشكلون نحو 53\% من إلجمالي ألقوى العاملة في البلاد

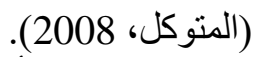
وقد مرت الأنشطة و الخدمات الإرشادية و الفنية التي

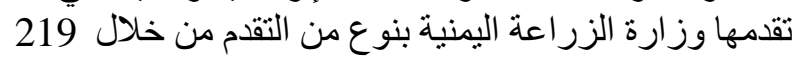

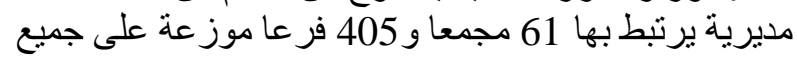

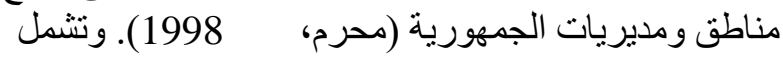

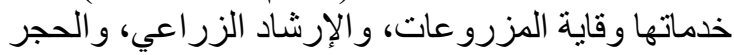

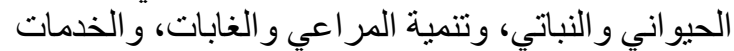

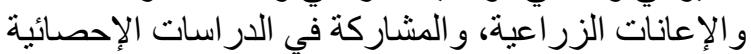

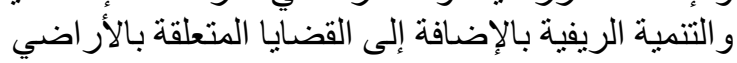

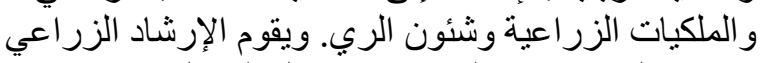

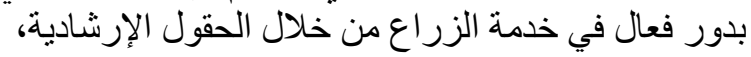

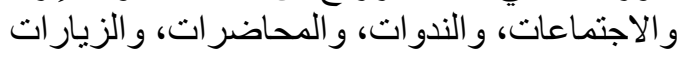

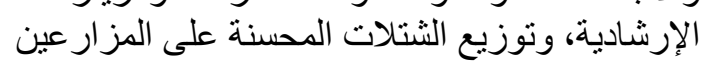

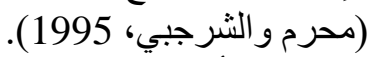

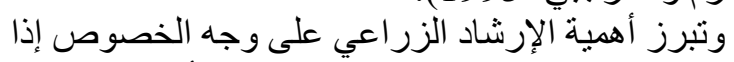

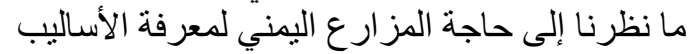

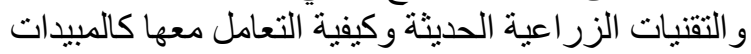

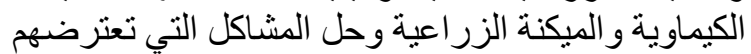

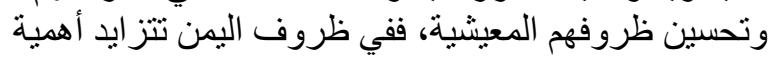

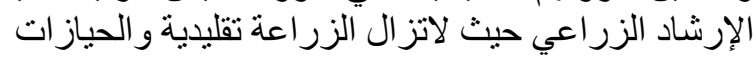

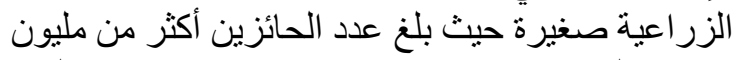

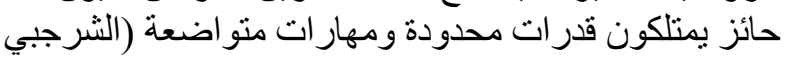

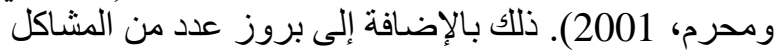

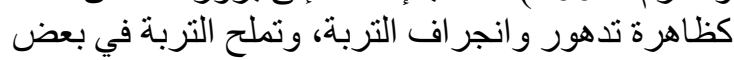

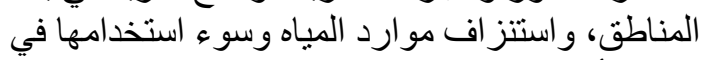
مناطق أخرى، وظهور وشناكل التسويق.

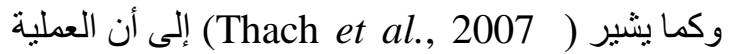

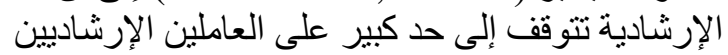

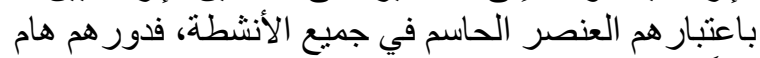

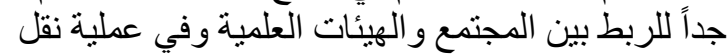
المعرفة و التكنولوجيا إلى المجتمع الريفي والزئن الزراع، فنجاح 
2. در اسة الخصائص الشخصية و الاجتماعية و الاقتصادية

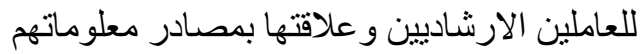

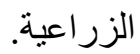

\section{2 - الطريقة البحثية}

مجتمع البحث

تغطي شاملة البحث جميع العاملين الإرشاديين الزر اعيين

في محافظتي شبوة وحضرموت و البالغ عددهم 158 عاملاً

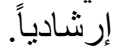

جمع البيانات

تم جمع البيانات الأولية للبحث عن طريث الاستبانة

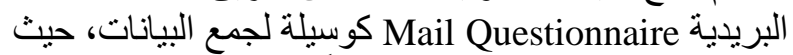

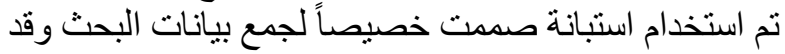

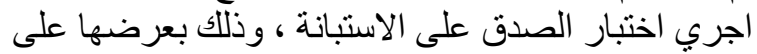

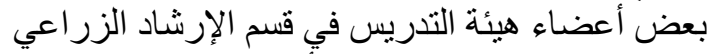

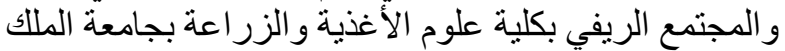

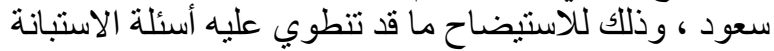

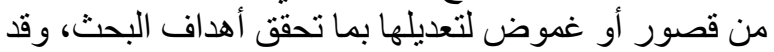

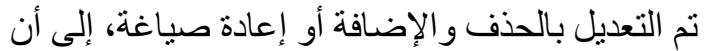

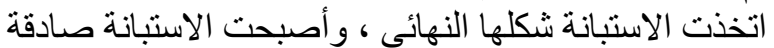
لقياس ما أعدت من أجله.

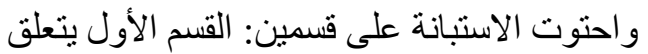

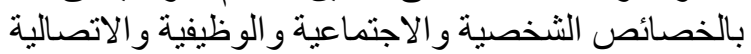

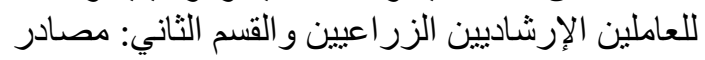

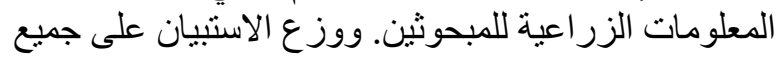

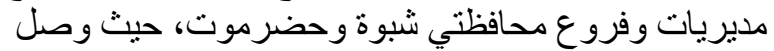
عدد الاستبانات المستوفاة 149 استبانة تشكل نسبة من العدد الإجمالي وذللك بعد استبعاد بعض الاستبيانات غير

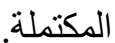
تحليل البيانات

شملت عملية تحليل البيانات عدة خطوات ومر احل حيث

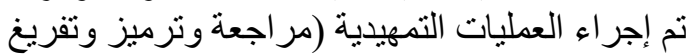

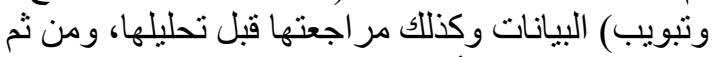
استخدام عدد من الأساليب الإحصائية في عملية التحليل فيليل

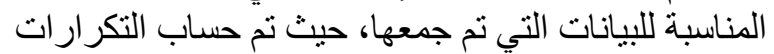
و النسب المئوية و المتوسط الحسابي و الانيان النحر اف المعياري

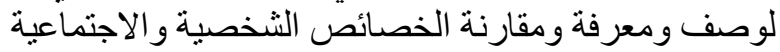

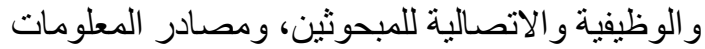

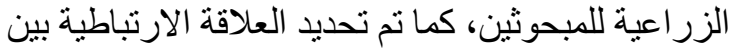

بعض الخصائص الثخصية ولئية والاجتماعية و الوظيفية

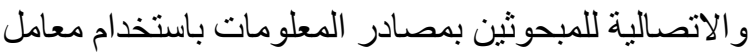

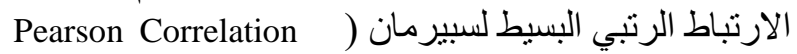

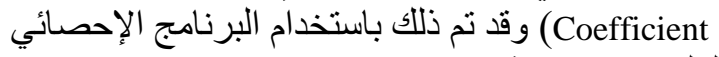
للعلوم الاجتماعية (CSS Base 17.0, 2012).

\footnotetext{
3 - نتائج البحث ومناقشتها

1.3. الخصائص الشخصية والاجتماعية والوظيفية للعاملين الإرشاديين
}

أن أهم المصادر التي يحصل منها العاملين الإرشـاديين في الزئي

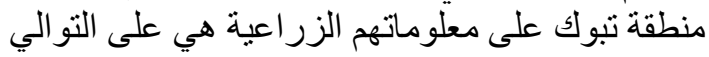

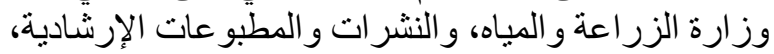

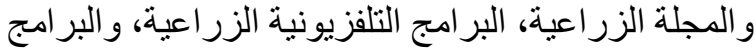
الإذاعية الزر اعية. أما أقلها أهمية فهي كلية الزراعة الزية الزية الزية الزية

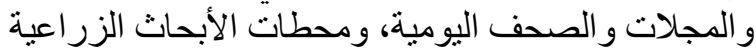

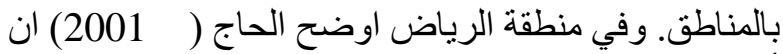

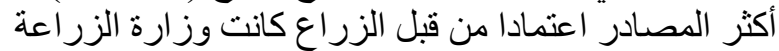

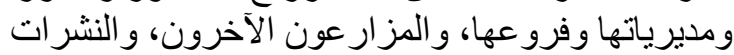

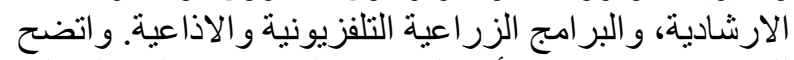

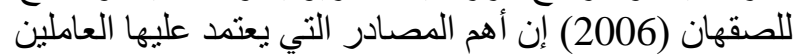

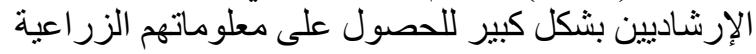

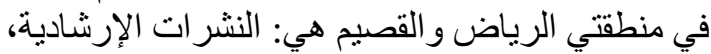

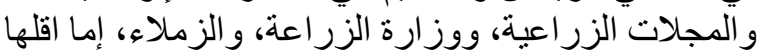
أهمية فهي المؤسسات و الثركات الثرات الزر اعية، وشبكة والزية

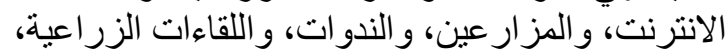

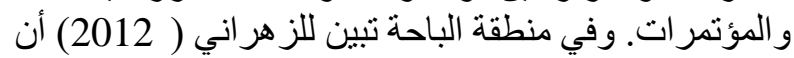

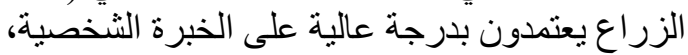

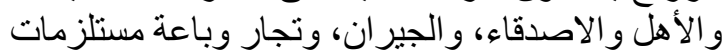

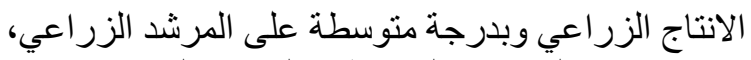

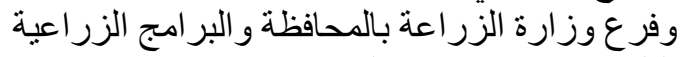

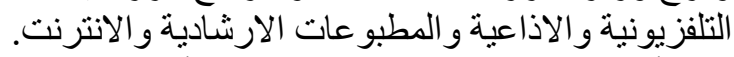

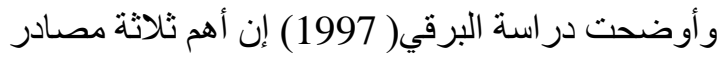

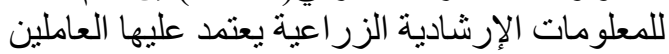

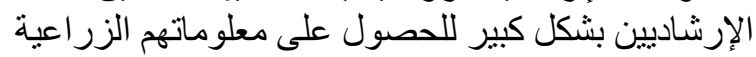

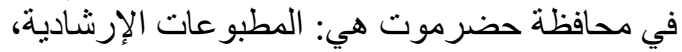

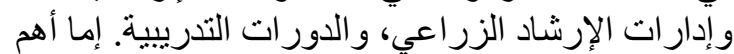

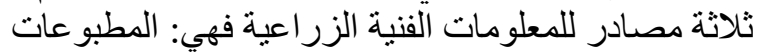

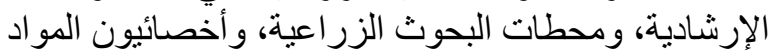

وأوضحت دراسة الأة الأديمي ( 2003) أن أهم مصادر الإرشادية.

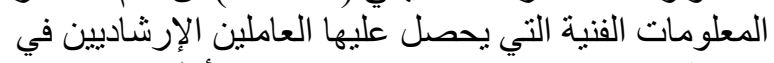

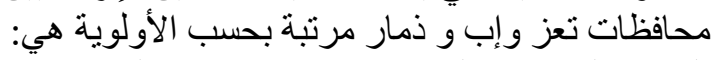

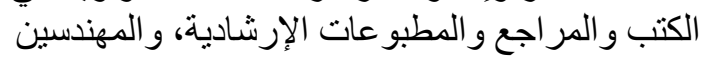

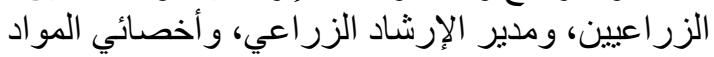

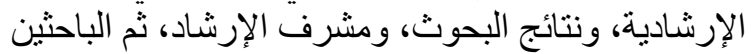

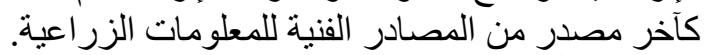

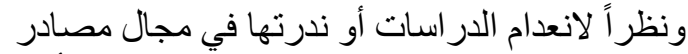

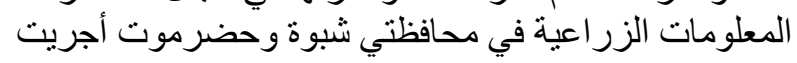

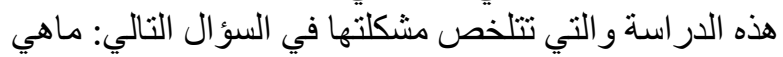

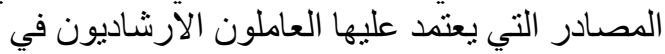

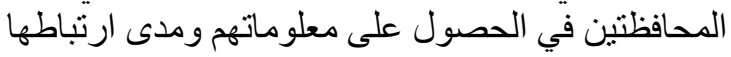

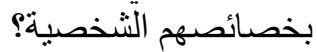
أ هداف البحث البهم

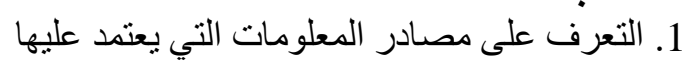

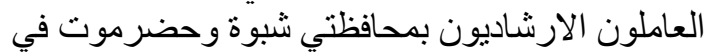
الحصول على معلوماتهم الزرأعية. 
الدراسات التي قام بها Melcr, Grambs, Phenix, و وغير هم،

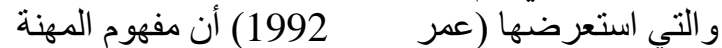

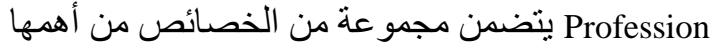

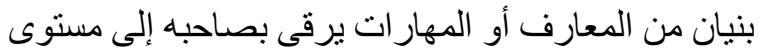
التخصص الأكاديمي أو الثهادة الجامعية الأولى على الألى القلى لئل ليعطيه البصيرة النافذة المميزة.

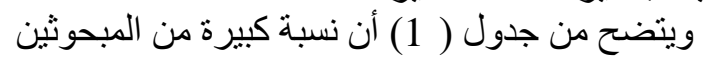

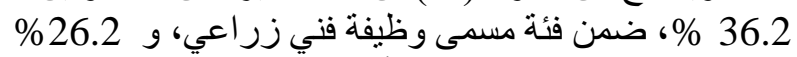

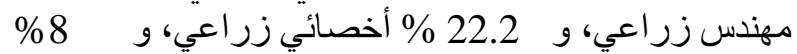

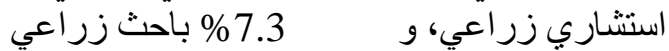

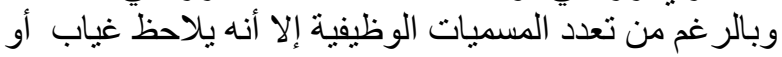

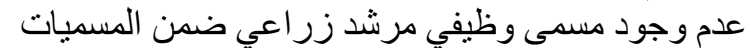

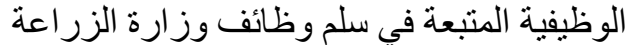

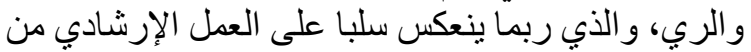

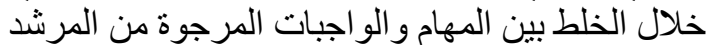

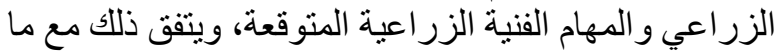

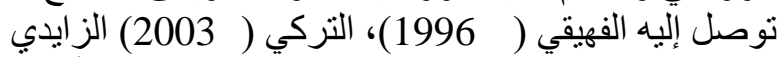

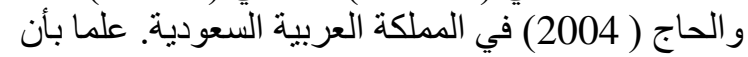
وظيفة مهندس زر اعي لا تعني العمل بالضرورة في في مجال التهال

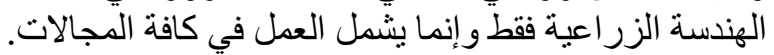

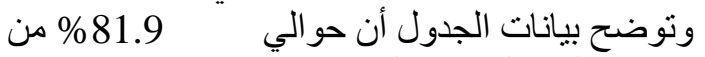

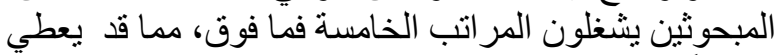

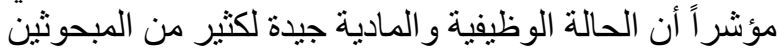
في الوقت الذي يوجد حوالي 18.1\% في المر اتب الأقل من

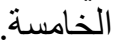

يعد المستوى الوظيفي الجيد من العو امل المؤشرة

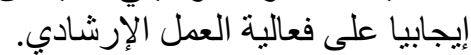

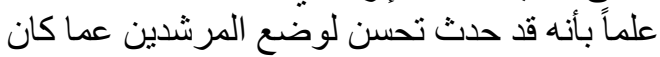

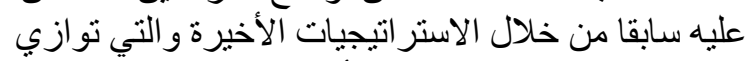

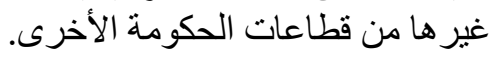

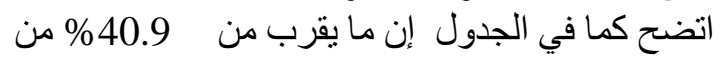

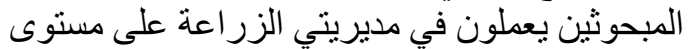

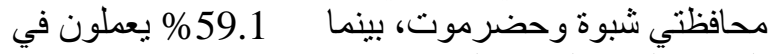
الفروع آلتابعة لهاتين المديريتين.

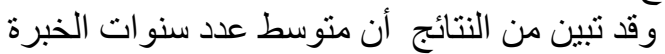

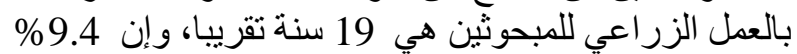
فقط من المبحوثين لا تتعدى خبر اتهم الزئ الزئ اعية خمس سنين.

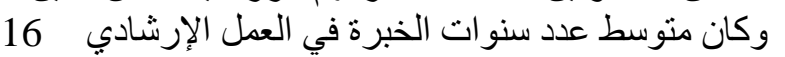
سنة، وقد بلغت نسبة الذين تقل خبرتهم عن \% 10.1

ومن خلال النتائج السابقة يتضح أن مستوى الخبرة،

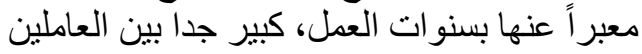

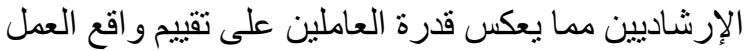

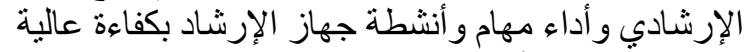
و هذا يتفق مع ما أنشار إليه (الكباشي، 1983).

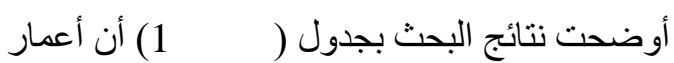

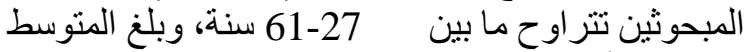

الحسابي لأعمار هم 42 سنة 42.067 سنة بانحر اف معياري قدره

8.067 درجه. و ويقع 22.8\% من المبحوثين في فئة

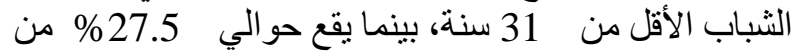

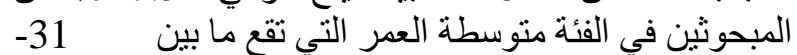

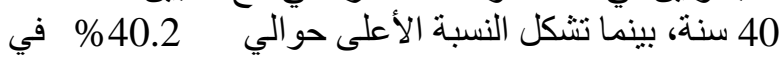

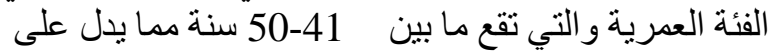
توفر عنصري الخبرة والثباب معاو اللذان يحتاجها العمل لئل الإرشادي لطبيعته المنركزة على العمل الميداني

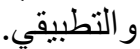
وتبين من الجدول أن نسبة كبيرة من المبحوثين

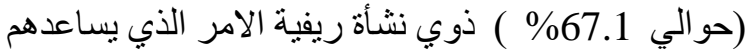
على تفهم بيئة المسترشدين و عاداتهم وتقاليد هم وكيفية

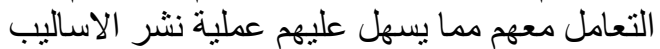

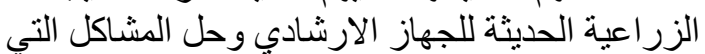
تو اجه الزراع و العمل الارشادي. ويتضح من الجدول ارتفاع الأنسبي للمستوى التعليمي

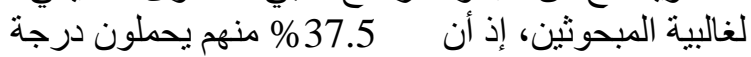

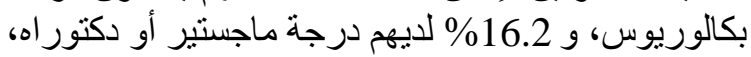

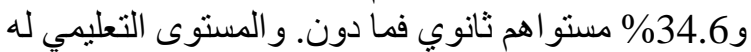

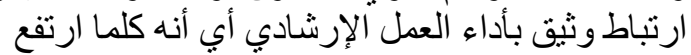

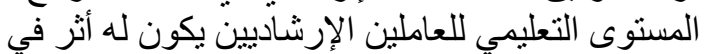

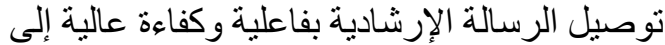

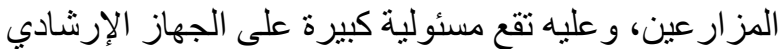
في منطقة البحث بالتأهيل الأكاديمي للعاملين الإرشاديين النارين.

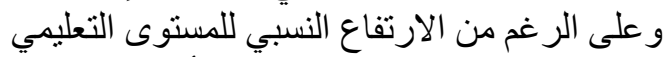

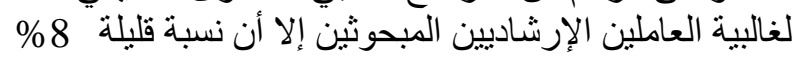

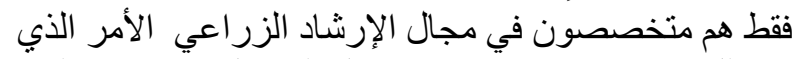

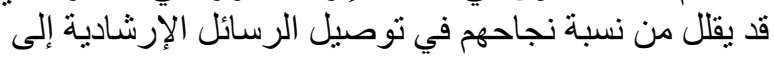

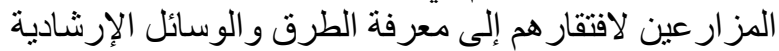

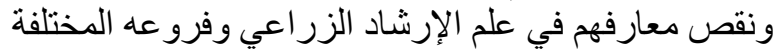

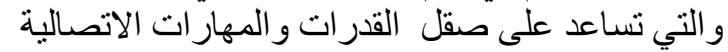

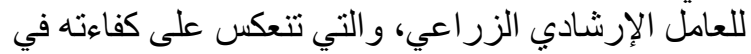

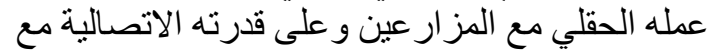
مر اكز البحث العلمي، و وعلى ذللك فإنه يجب الإنه الإنمام

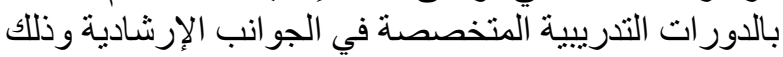

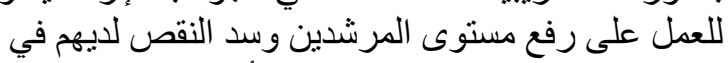

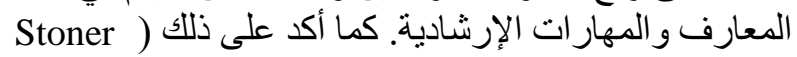
(and Freeman 1992

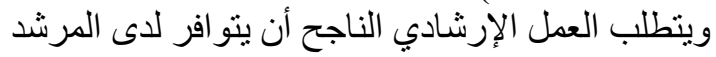

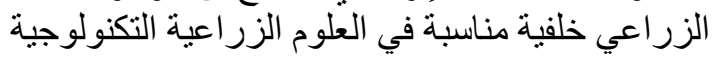

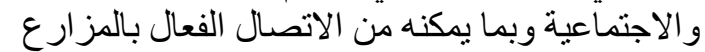
ووضع الرسالة الإرشادية التي يحملها إليها في الإليه صورة مفهومة ومؤثرة (الخولي، الإني، 1968). كما أوضحت 
جدول(1): الخصائص الثخصية والاجتماعية والوظيفية للعاملين الارشاديين (ن=149)

\begin{tabular}{|c|c|c|c|c|c|}
\hline$\%$ & عدد & الخصائص & $\%$ & عدد & الخصائص \\
\hline \multicolumn{3}{|r|}{ مسمى الوظيفية } & \multicolumn{3}{|r|}{ العمر } \\
\hline 36.2 & 54 & فني زراعي & 22.8 & 34 & 30-27 سنة \\
\hline 26.2 & 39 & مهندس زراعي & 27.5 & 41 & $40-31$ \\
\hline 22.2 & 33 & اخصائي زراعي & 40.3 & 60 & $50-41$ \\
\hline 8.0 & 12 & استشاري زراعي & 9.5 & 14 & 51 سنة فأكثر \\
\hline 7.3 & 11 & باحث زراعي & \multicolumn{3}{|r|}{ مكان الميلاد } \\
\hline \multicolumn{3}{|r|}{ المرتبة الوظيفية } & 67.1 & 100 & ريف \\
\hline 18.1 & 27 & الثانية- الرابعة & 32.9 & 49 & حضر \\
\hline 23.5 & 35 & الخامسة_ السابعة & \multicolumn{3}{|r|}{ المؤهل العلمي } \\
\hline 34.2 & 49 & الثامنةــ العاشرة & 5.4 & 8 & متوسط وما فُوق \\
\hline 17.5 & 26 & الحادية عشر-الثالثة عشر & 6.7 & 10 & دبلوم متوسطزراعي \\
\hline 6.7 & 10 & الرابعة عشر فما فوق & 14.8 & 22 & ثثانوي عام \\
\hline \multicolumn{3}{|r|}{ مكان العمل ع } & 9.8 & 14 & دبلوم ثانوي زراعي \\
\hline 59.1 & 88 & فرع & 10.0 & 15 & دبلوم عالي زراعي \\
\hline 40.9 & 61 & مديرية & 37.5 & 56 & بكالوريوس \\
\hline \multicolumn{3}{|r|}{ سنوات الخبرة } & 13.4 & 20 & ماجستير \\
\hline 9.4 & 14 & 5 سنوات فأقل & 2.8 & 4 & دكتوراه \\
\hline 12.8 & 19 & 10-6 سنوات & \multicolumn{3}{|r|}{ التخصص العلمي } \\
\hline 11.4 & 17 & | 11 -11 سنة & 8.01 & 21 & إرشاد زراعي \\
\hline 20.11 & 30 & (16- 20 سنة & 92.0 & 137 & تخصص زراعي غير الارشـاد \\
\hline 46.3 & 69 & 21 سنة فما فوق & \multicolumn{3}{|r|}{ سنوات الخبرة فَّي العمل الارشادي } \\
\hline \multicolumn{3}{|r|}{ التذريب قبل باية الخدمة } & 10.1 & 15 & 5 سنوات فأقّل \\
\hline 5.4 & 8 & حصل على تدريب & 15.4 & 23 & 6- 10 سنوات \\
\hline 94.6 & 141 & لم يحصل على تدريب & 20.8 & 31 & 15-11 سنة 15 سنة \\
\hline \multicolumn{3}{|r|}{ التّريب أثثاء الخدمة } & 19.5 & 29 & 16- 20 سنة \\
\hline 92.6 & 138 & نعم التحق & 34.2 & 51 & 21 سنة فما فوق \\
\hline 7.4 & 11 & لا لم يلتحق & & & \\
\hline
\end{tabular}

عليها المبحوثون بشكل كبير في الحصول على معلوماتهم

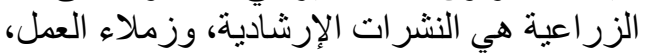

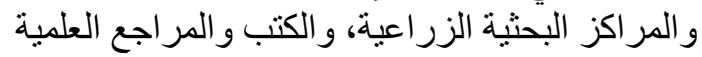

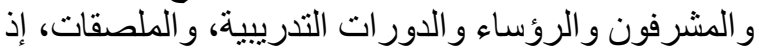

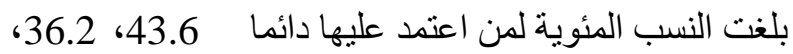

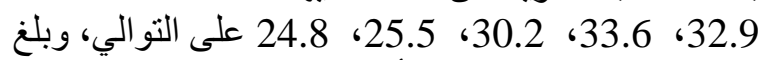
المنوسط الحسابي لكل منها أعلى من مقياس مستوى درجة الاعتماد الثنلاثي. بينما كان المتوسط الإني

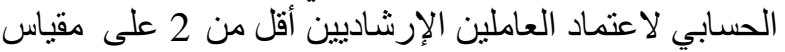

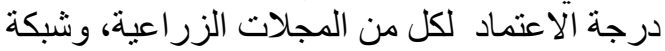

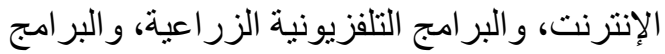

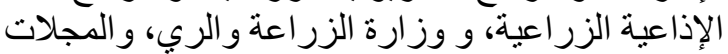

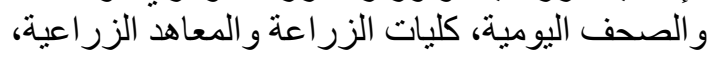

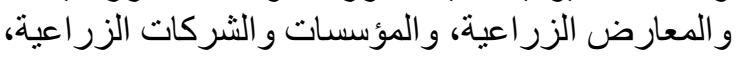

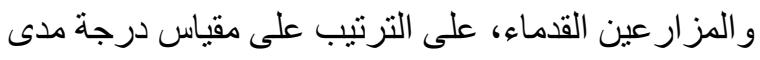

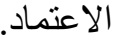

يتضح من النتائج السابقة مدى اعتماد العاملين بشكل

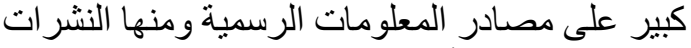

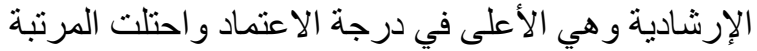

الاولى مما يدل على أهمية توفر النشر الزئ الات في مديريات

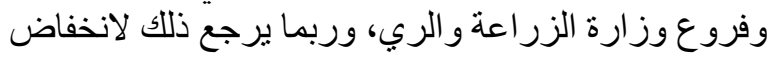

يعد مدة الخدمة في العمل مؤشر ا جيدا يمكن الاعتماد عليه

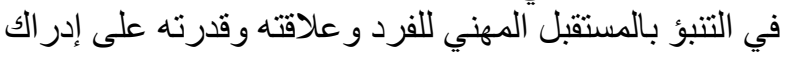

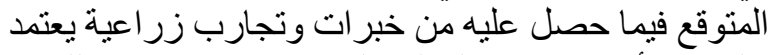

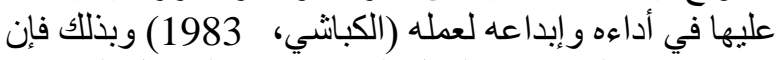

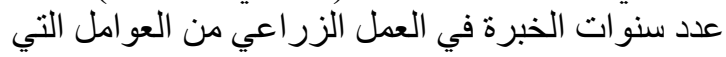

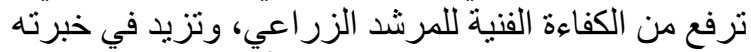

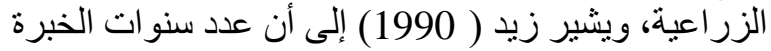

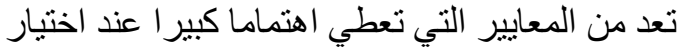

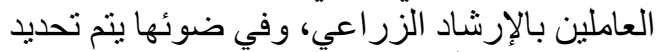

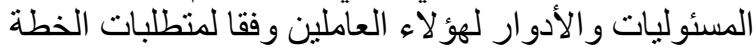
المطلوب تنفيذها.

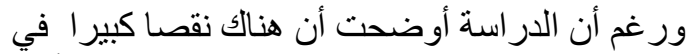

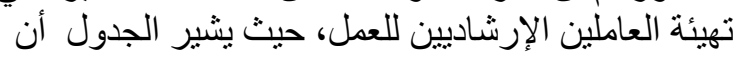

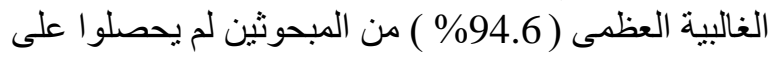

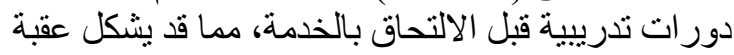

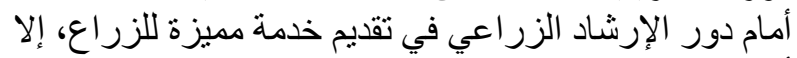

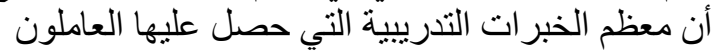

الإرشاديون كانت من خلال التدريب أثناء الخدمة (بنسبة

. مصادر المطلومات ومستوى الاعتماد عليها ويتضح من الجدول (2) أن أهم المصادر النئو التي يعتمد 
جدول (2): توزيع المبحوثين وفقا لمصادر المعلومات التي يعتمد عليها العاملون بلإنشاد.

\begin{tabular}{|c|c|c|c|c|c|c|c|c|}
\hline \multirow{2}{*}{ الانحراف } & \multirow{2}{*}{ الحستوسط } & \multicolumn{2}{|c|}{ نادرا } & \multicolumn{2}{|c|}{ أحيانا } & \multicolumn{2}{|c|}{ دائما } & \multirow{2}{*}{ مستوى الاعتماد } \\
\hline & & $\%$ & عدد & $\%$ & عدد & $\%$ & عدد & \\
\hline ,679 & 2.32 & 12.1 & 18 & 44.3 & 66 & 43.6 & 65 & النشرات الإرشادية \\
\hline ,690 & 2.21 & 15.4 & 23 & 48.3 & 72 & 36.2 & 54 & زملاء العمل \\
\hline ,640 & 2.21 & 12.1 & 18 & 55 & 82 & 32.9 & 49 & المراكز البحثية الزراعية \\
\hline 1,020 & 2.20 & 5.1 & 29 & 46.3 & 69 & 33.6 & $\mathbf{5 0}$ & الكتب والمراجع العليمة \\
\hline ,710 & 2.09 & 20.8 & 31 & 49 & 73 & 30.2 & 45 & المشرفين والرؤساء \\
\hline, 659 & 2.07 & 18.1 & 27 & 56.4 & 84 & 25.5 & 38 & الدورات التدريبية \\
\hline, 660 & 2.06 & 18.8 & 28 & 56.4 & 84 & 24.8 & 37 & الملصقات \\
\hline, 612 & 1.83 & 28.9 & 43 & 59.7 & 89 & 11.4 & 17 & المجلات الزراعية \\
\hline ,763 & 1.79 & 40.9 & 61 & 37.7 & 56 & 21.5 & 32 & شبكة الإنترنت \\
\hline ,711 & 1.77 & 39.6 & 59 & 44.3 & 66 & 16.1 & 24 & البرامج التلفزيونية الزراعية \\
\hline, 650 & 1.68 & 42.3 & 63 & 47.7 & 71 & 10.1 & 15 & البرامج الإذاعية الزراعية \\
\hline ,755 & 1.68 & 49 & 73 & 33.6 & 50 & 17.4 & 26 & وزارة الزراعة \\
\hline ,648 & 1.64 & 45 & 67 & 45.6 & 68 & 9.4 & 14 & المجلات والصحف اليومية \\
\hline ,600 & 1.52 & 53.7 & 80 & 40.9 & 61 & 5.4 & 8 & الزياعية الزراعة والمعاهد \\
\hline ,640 & 1.37 & 71.8 & 107 & 19.5 & 29 & 8.7 & 13 & المعارض الزراعية \\
\hline, 536 & 1.32 & 71.1 & 106 & 25.5 & 38 & 3.4 & 5 & المؤسسات والثركات الزراعية \\
\hline, 491 &, 60 & 57.2 & 112 & 18.8 & 28 & 6 & 9 & المزارعين القدماء \\
\hline
\end{tabular}

في المرتبة الثانية، و المشرفون و الرؤساء في المرتبة

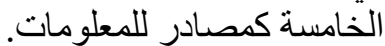
و على الرغم من أن شبكة الإنترنت تعد من مصاد المبادر

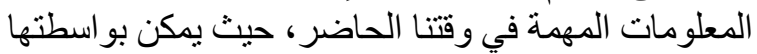

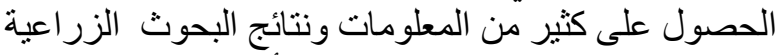
و الإرشادية من مختلف دول العالم، إلا أن الاعتماد الإن عليها

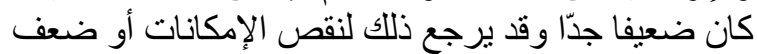
التأهيل لاى العاملين الإرشاديين مما يعكس الحاجة الإنات الماسة

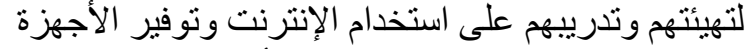

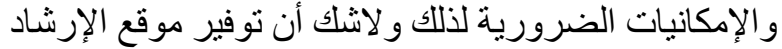
الزراعي في شبكة الإنترنت تتوفر فيه كافة المعلومات الإنية الفنية الإنية

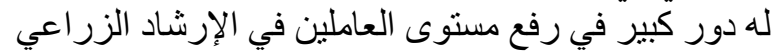

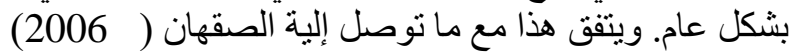
في المملكة العربية السعودية.

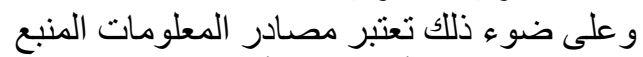

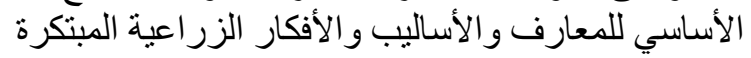

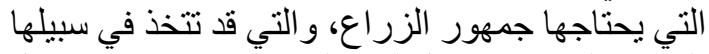

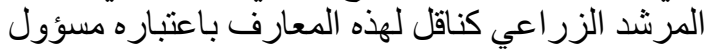

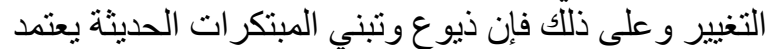

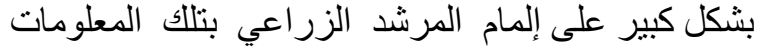

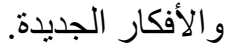

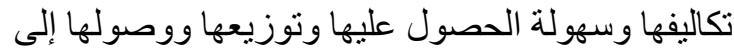

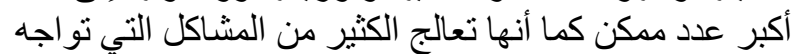

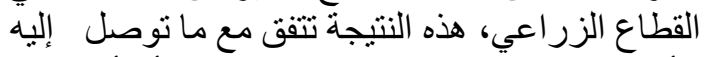

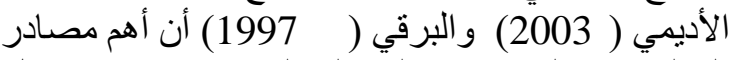

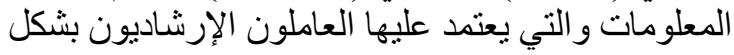

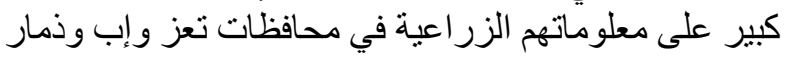
وحضرموت هي: النشرات الإرشّادية، و الصقهان ( 2006) في المملكة العربية السعودية.

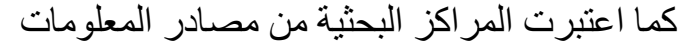

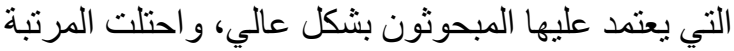

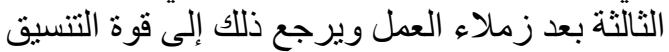
و التعاون بشكل عام بين هذه المر اكز و الجهاز الإرشادي التهادي

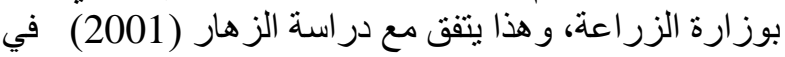

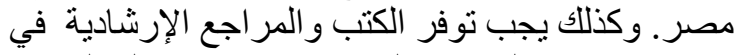

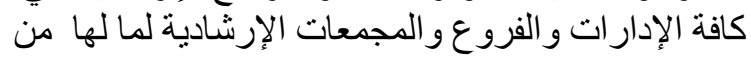

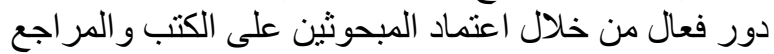

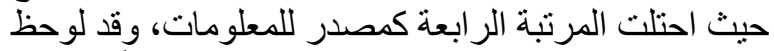
أن الدور ات التدرييية قد احتلت مرتبة متأخرة نسبياً حيث

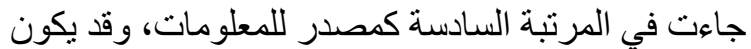

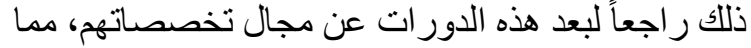

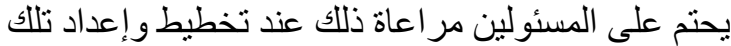
الدور ات وخاصة الدور ات الإرشادية. كما جاء زملاء العمل 


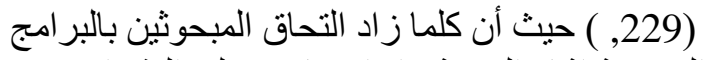

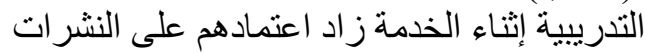

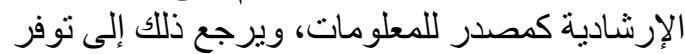
النشر ات الإرشادية في الدور ات التدرييية للعاملين

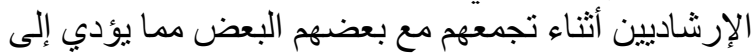

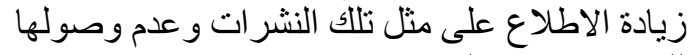

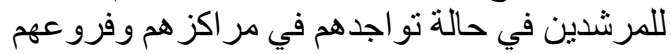
ومجمعاتهم الإرشادية.

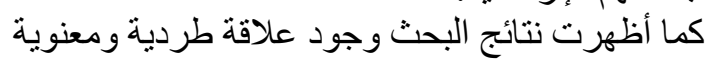

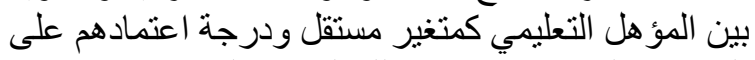

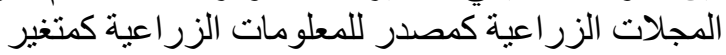

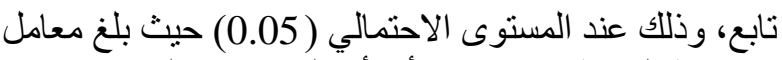

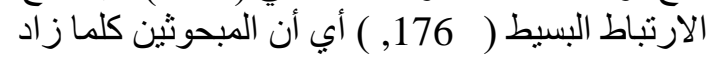

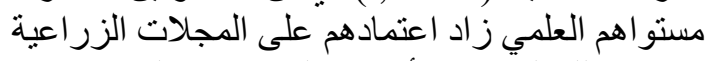

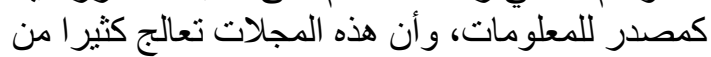

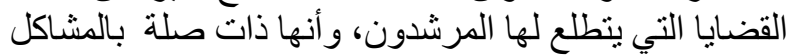
الزر اعبة الر اهنة.

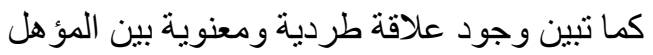

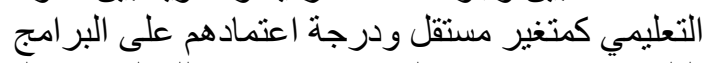

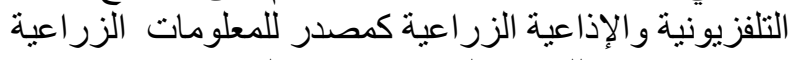

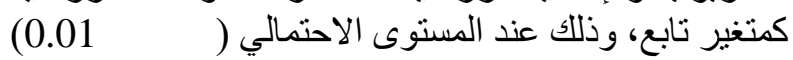

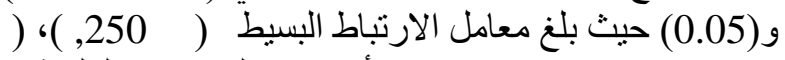

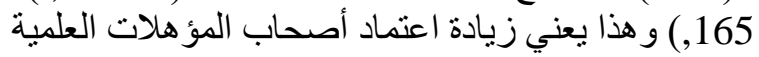

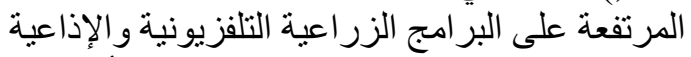

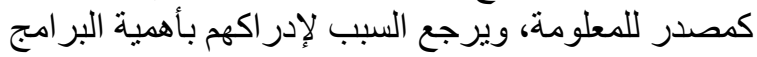

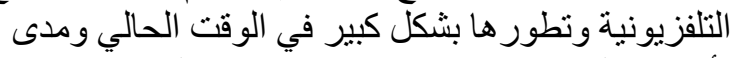

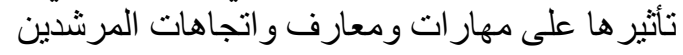

و اتضح أيضا وجود علاقة ارتباطية طردية ومعنوية العندية

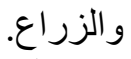

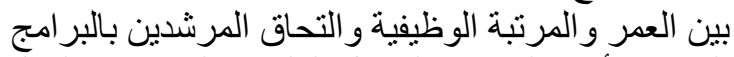

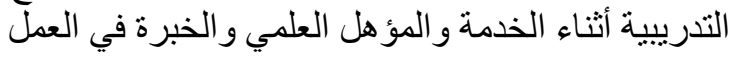

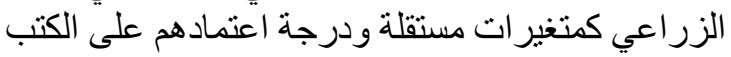

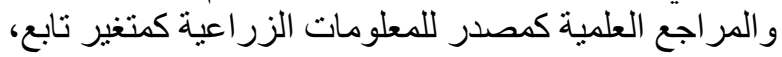

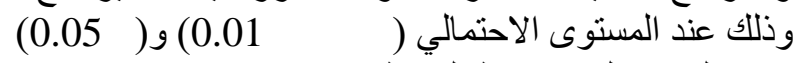

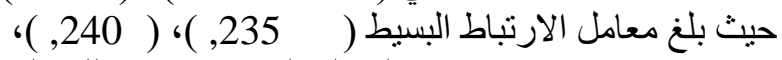

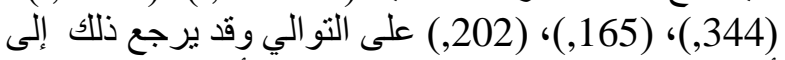

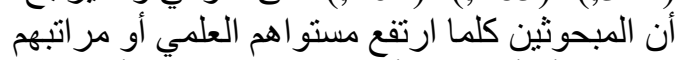

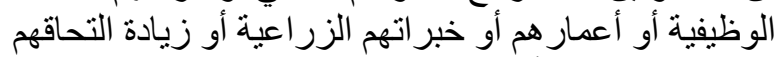

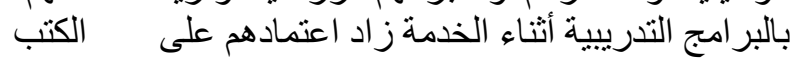

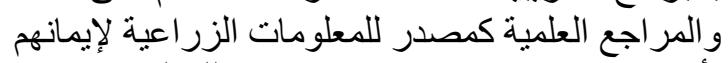

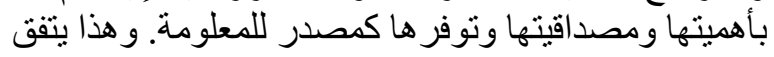

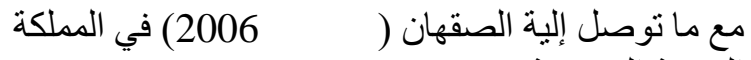
العربية السعودية.

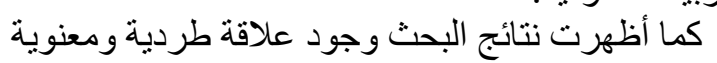

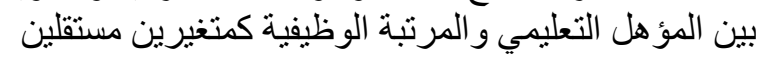

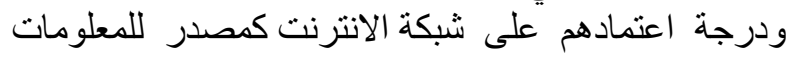

العلاقة الارتباطية بين بعض الخصائص الثخصية

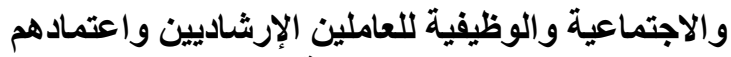

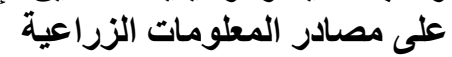
لللتعرف عصلى مدى المعلى ارتباط كل من الزراعة الخصائص الثخدية

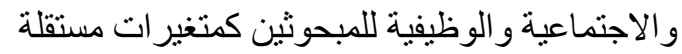

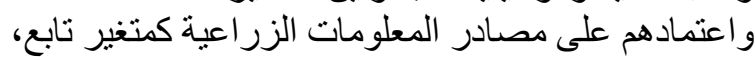

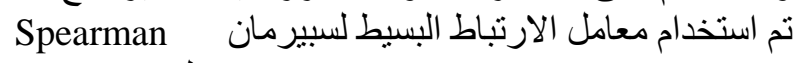
correlation coefficient علاقة ارتباطيه عكسية ومعنوية بين كل من العمر وعنين العند

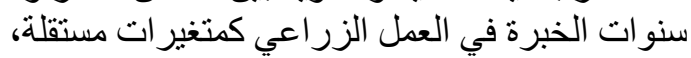

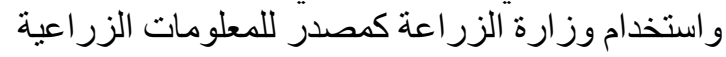

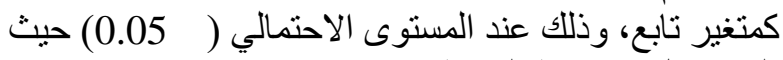

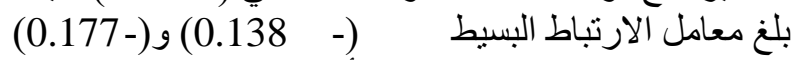
على التوالي، وقد يرجع ذلاطي اللك إلى أن المبحوثين من كبار

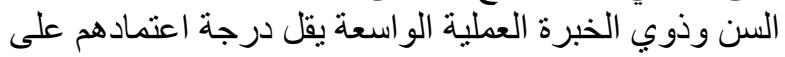

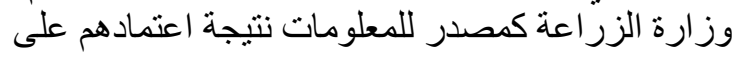

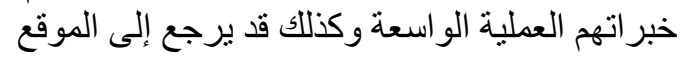

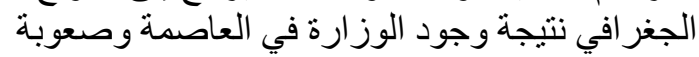

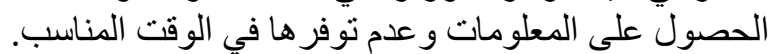

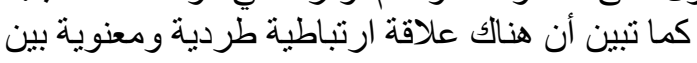

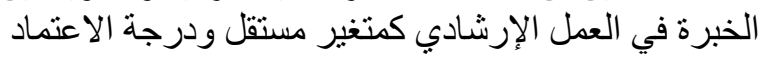

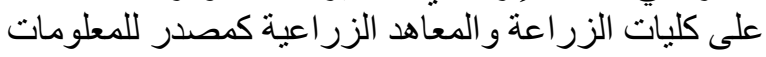

الزر اعية كمتغير تابع، وذلاعة اللك عند المستوى الاعند الاحتمالي (0.01) حيث يبلغ معامل الارتباط البسيط (

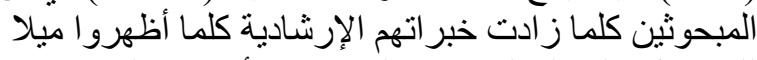

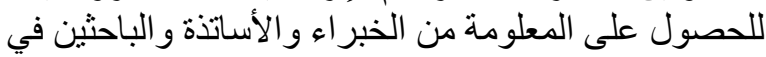

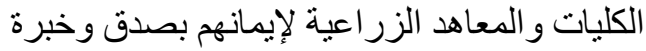

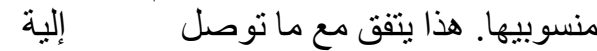

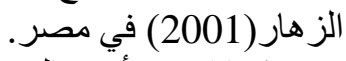

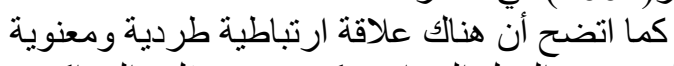

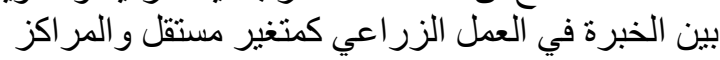

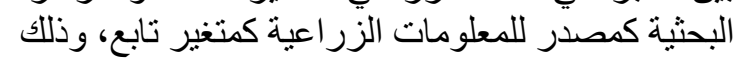

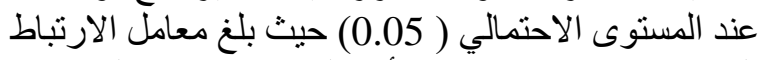

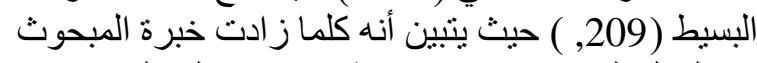

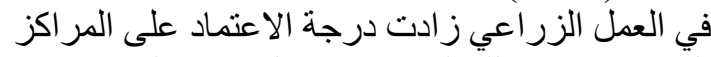

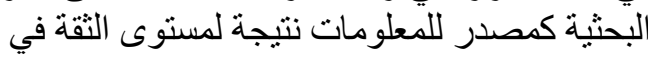

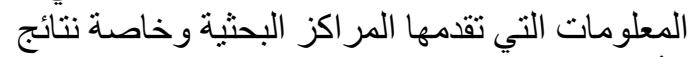

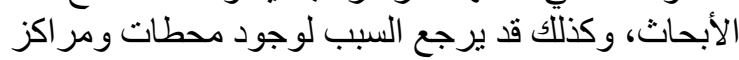

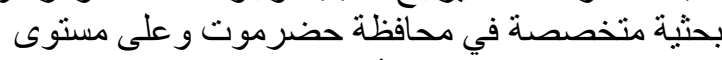

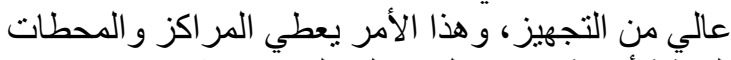

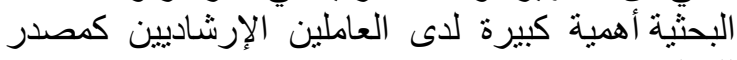
لالمعلومات.

كما تبين أن هنالك علاقة طردية ومعنوية بين التحاق

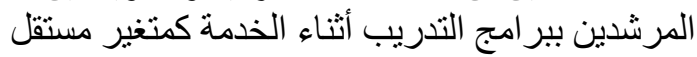

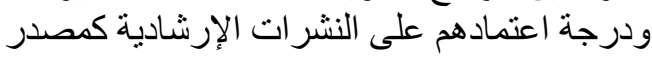

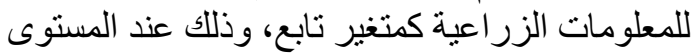

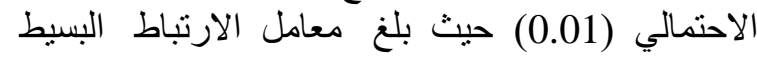


جدول (3): العلاقة الارتباطية بين بعض الخصائص الثخصية والاجتماعية والوظيفية مع مصادر المعلومات التي يعتمد عليها العاملين الإرشاديين باستخدام معامل الارتباط البسيط لسبيرمان ( Spearman correlation coefficient):

\begin{tabular}{|c|c|c|c|c|c|c|}
\hline \multicolumn{6}{|c|}{ الخصائص الثخصية } & \multirow[b]{2}{*}{ مصادر المعلومات } \\
\hline بيرنامج تلاريبيِ & الإلثبرة في العمل & العمل الزبرة في & الوظيفية & التعليمي هل & 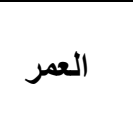 & \\
\hline ,66- & ,107- & *,177- & ,155- & ,019- & *,138- & وزارة الزراعة \\
\hline ,019- & ** ,255 & ,144- & ,169- &, $55-0$ & ,123- & كليات الزراعة والمعاهد \\
\hline ,009- & *,209 & ,087- & ,045- & ,059- & ,016- & المراكز البحثية \\
\hline ** ,229 & ,74 & ,141- & ,175 & ,036- & ,117- & النشرات الإرشـادية \\
\hline ,111 & ,113 & ,104- & ,123- & ,053- & ,070- & الملصقات \\
\hline ,104 & ,225 & ,094 & ,079 & ${ }^{*}, \mathbf{1 7 6}$ & ,142 & المجلات الزراعية \\
\hline ,139- & ,096- & ,008- & ,003- & ** 250 & ,081 & البرامج الإذاعية الزراعية \\
\hline ,093 &, 113 & ,063- & ,062- & ${ }^{*}, 165$ & ,002- & البرامج التلفزيونية الزراعية \\
\hline **, 344 & ,157 & * ,202 & **, 240 & ${ }^{*}, 165$ & ** ,235 & الكتب والمراجع العلمية \\
\hline ,170 &, 108 & ,009- &, 007 & ,199- &, 054 & الدورات التدريبية \\
\hline ,018 & ,088- & ,046- & ,032- & ,064- & ,041 & الزراعية المسات والثركات \\
\hline ,099 &, 023 & ,147- & ${ }^{*}, 205$ & *,208 & ,007- & شبكة الاتترنت \\
\hline ,197 &, 141 & ,071- &, $\mathbf{0 5 0}-$ & ,056 & ,113- & المسئولون والرؤساء \\
\hline ,097 & ,009 & ,014- & ,010 & ,157- & ,048 & المعارف الزراعية \\
\hline, 066 & ,096- & ,168 &, 166 & ,092- &, 068 & المجلات والصحف اليومية \\
\hline, 324 &, 002 & ,077- & ,097- & ,004- & ,052- & زملاء العمل \\
\hline, 032 & ,069- & ,062- &, 020 &, 024 &, 027 & المزارعون الكبار ذوي الخبرة \\
\hline & & ل إلد مستوى & & & & * * مغنويةّ عند مستوى 0.01 \\
\hline
\end{tabular}

التدريبية المتخصصة في الجو انب الإرشادية لانخفاض إلإ

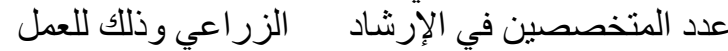

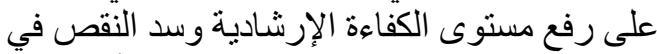

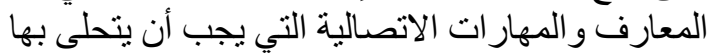

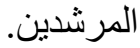

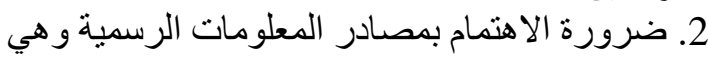

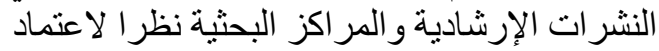

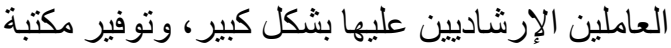

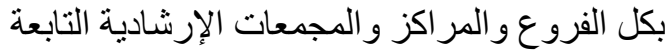

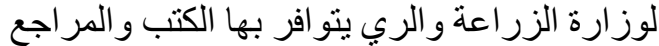
العلمية وأحدث النشر ات الزات الإرشادية و المجلات الترات

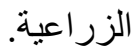

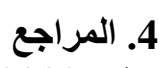

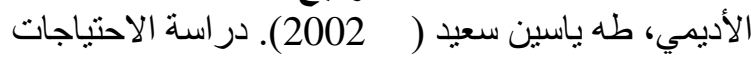
التدرييية للعاملين الإرشاديين في مجال التنمية
الزر اعية كمتغير تابع، وذلك عند المستوى الاحتمالي

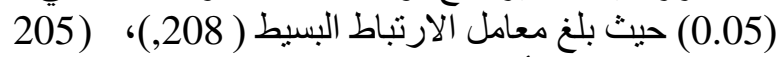

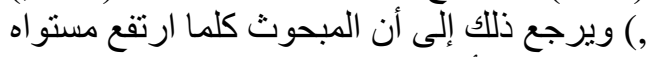

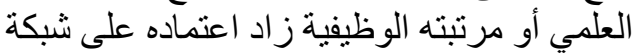

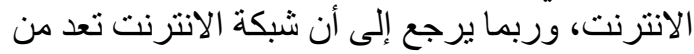

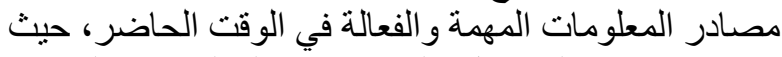

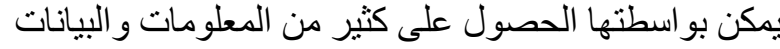

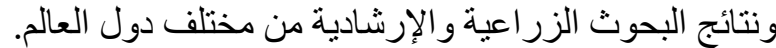
و هذا يتقق مع ما توصل إلئه الزيه الحوسني (1999) في الإمار ات العربية المتحدة. التوصيات

في ضوء ما توصل إلبه البحث من نتائج يوصى بالآتي:

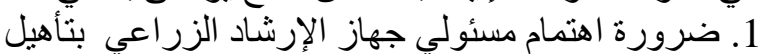
وتدريب العاملين الإرشاديين، خاصة الدورئ الزّرات 


$$
\begin{aligned}
& \text { كلية علوم الأغذية و الزر اعة، جامعة الملك سعود، }
\end{aligned}
$$

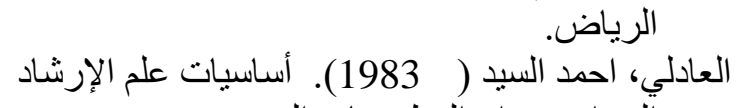

$$
\begin{aligned}
& \text { الزر اعي، دار المطبو عات الجديدة. }
\end{aligned}
$$

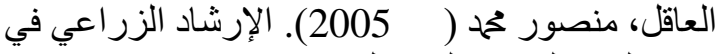

$$
\begin{aligned}
& \text { اليمن الو اقع و المستقبل، صنعاء. } \\
& \text { الفهيقي، غالي مبارك ( 1996). و القع العمل الإرشادي }
\end{aligned}
$$

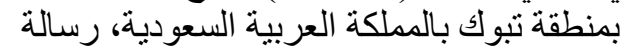

$$
\begin{aligned}
& \text { ماجستير ، كلية الزر اعة، جامعة الملك سعودة، }
\end{aligned}
$$

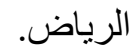

$$
\begin{aligned}
& \text { الكبانشي، أحمد دفع الله ( 1983). دور وفعالية الصحافة }
\end{aligned}
$$

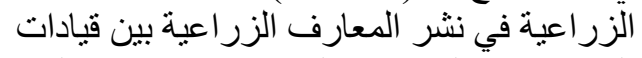

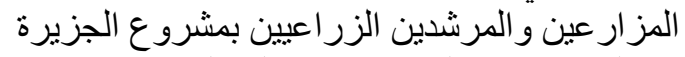

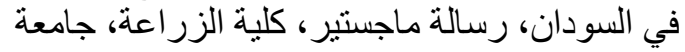

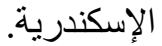

$$
\begin{aligned}
& \text { المتوكل، ماجد هاثشم ( 2008). الوضع الر اهن للإِدارة }
\end{aligned}
$$

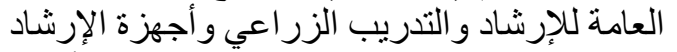

$$
\begin{aligned}
& \text { الزر اعي في عموم الجمهورية، تقرير شامل، الزئ، أكتوبر. }
\end{aligned}
$$

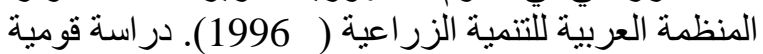

$$
\begin{aligned}
& \text { حول تطوير فاعلية أجهزة الإرشاد الزراعية في الزية }
\end{aligned}
$$

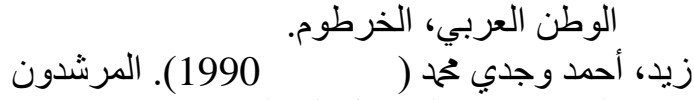

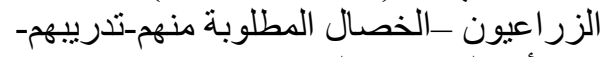

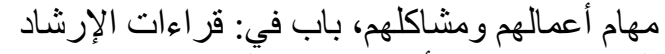

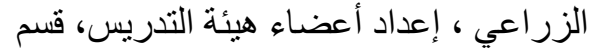

$$
\begin{aligned}
& \text { الإرشاد الزراعي ، كلية الزراعة اعة ، جامعة اللزية }
\end{aligned}
$$

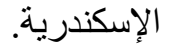

$$
\begin{aligned}
& \text { عمر، احمد محمد ( 1992). الإرشاد الزر اعي المعاصر، } \\
& \text { مصر للخدمات العلمية، القاهرة. }
\end{aligned}
$$

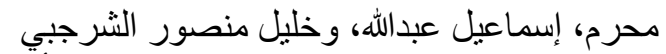

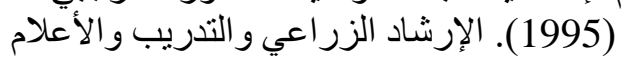

$$
\begin{aligned}
& \text { في اليمن، صنعاء-دار المجد للطباعة و النشر. }
\end{aligned}
$$

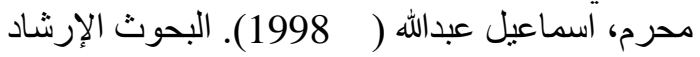

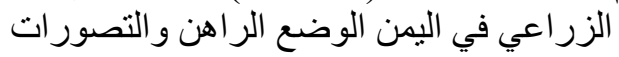

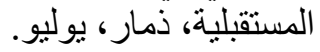

Stoner J. A. F., and Freeman B. E. (1992). Management (5th ed.). New Delhi: prentice- Hall of India.

Teach N. I small M. Uli, Indris K. (2007). Individual factors as predicators of extension agents performance in Mekong Delta, Vietnam. The Journal of Human Resource and Adult Learning vol. 3, Nam. I, July 2007. pp 93-102.

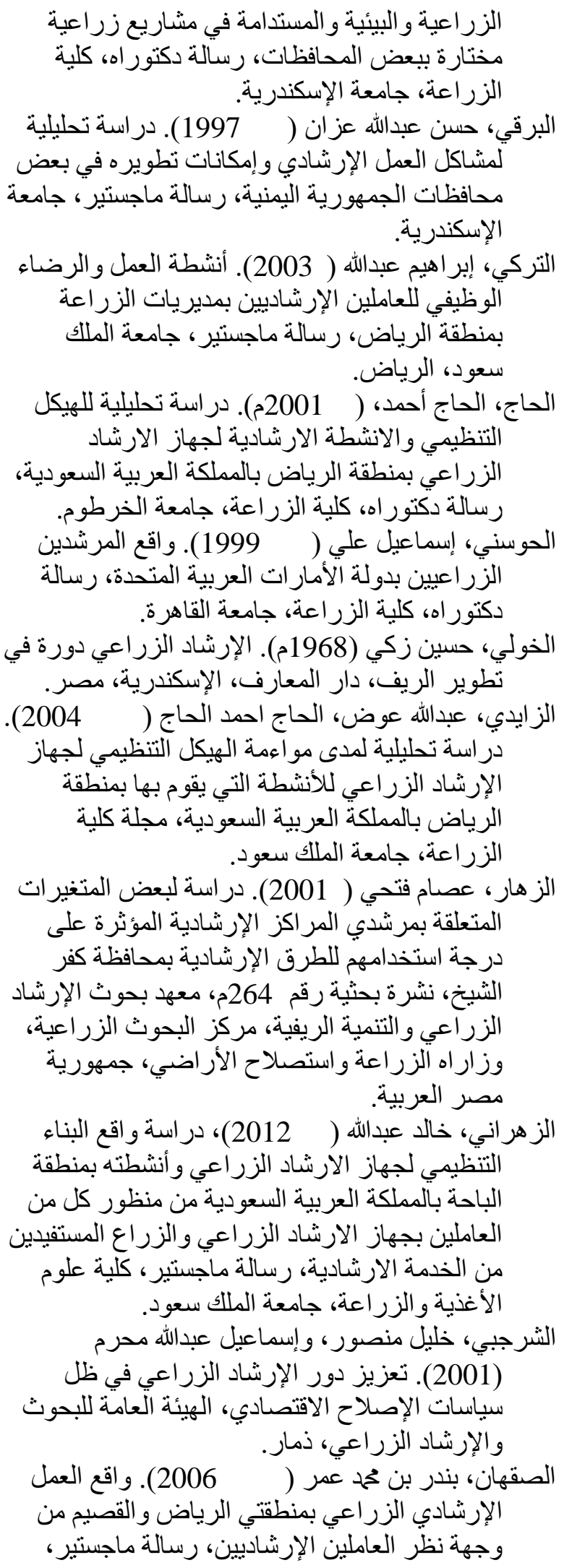

الزر اعية و البيئية و المستدامة في مشاريع زر اعية الزر اعة، جامعة الإسكندرية.

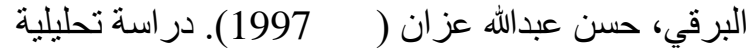

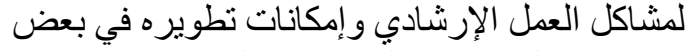
الإسكندرية.

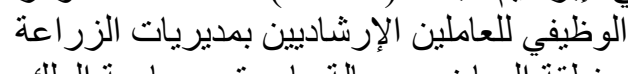

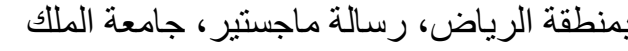

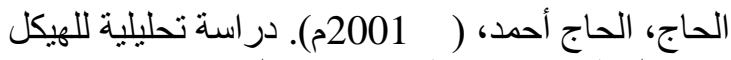

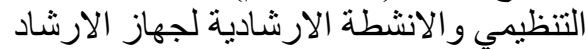
الزر اعي بمنطقة الرياض بالمملكة العربية السعودية الإنية،

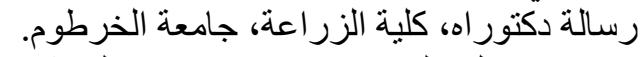

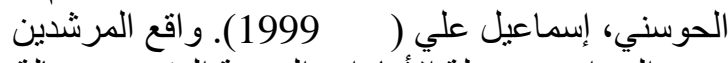

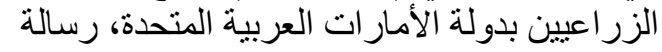
دكتور اه، كلية الزر اعة، جامعة القاهرة.

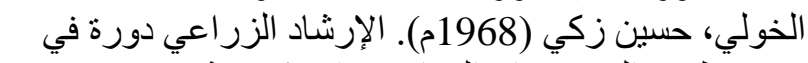

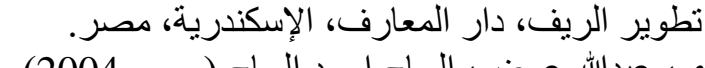
الزايدي، عبدالله عوض، الحاج الحاج احمد الحاج ( 2004). در اسة تحليلية لمدى مو اءمة الهيكل التنظيمي لجهاز

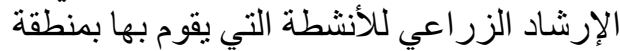
الرياض بالمملكةٌ العربية السعودية، الزية، مجلة كلية الزر اعة، جامعة الملك سعود د.

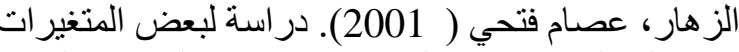
المتعلقة بمرشدي المر اكز الإرشادية المؤثرة على لمئي

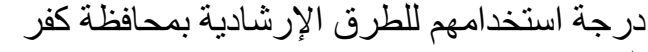
الثيخ، نشرة بحثية رقم 264م، معهز بحوث الإثة الإرشاد

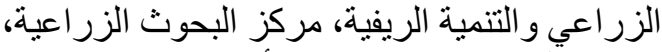

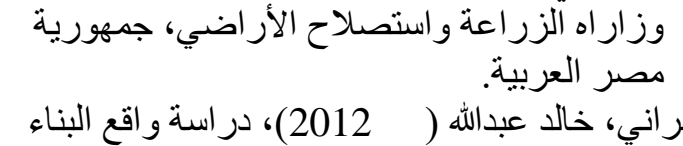

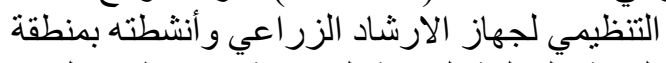

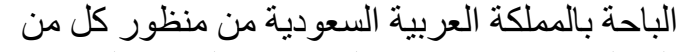

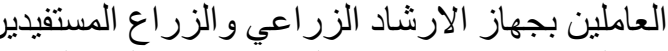

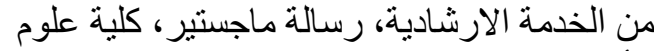
الأغذية و الزر اعة، جامعة المادية الملك سعود د.

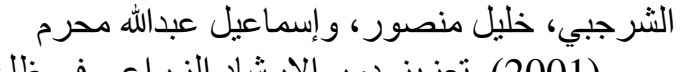

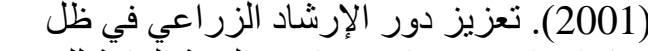

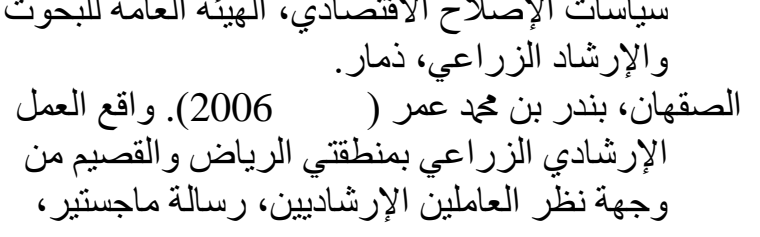

